\title{
The world after the novel coronavirus -- Take Africa as an example
}

\author{
Degreume \\ DOI: 10.29322/IJSRP.11.01.2021.p10965 \\ http://dx.doi.org/10.29322/IJSRP.11.01.2021.p10965
}

\begin{abstract}
The novel coronavirus has been sweeping the globe. According to the previous researchers, it is another major infectious disease after human beings suffer from malaria, cholera, Ebola virus etc. This disease appeared at the end of 2019 year and is named "2019 new corona virus" by the World Health Organization (WHO), which is called "covid-19" for short. It has a great impact on human society compared with malaria, Ebola and AIDS, and has also caused great losses to all countries in the world. This study focuses on the situation of world after the pandemic, in particular African countries. This objective was investigated using a comprehensive method of documentary review and interview. In this paper, the status and trend of African Development under the influence of the pandemic are discussed. Through this paper, the African people and other people can have a deeper understanding of Africa's situation after this pandemic. This study also put forward some solutions to different crises that African countries will face after the pandemic.
\end{abstract}

Index Terms- Africa, epidemic situation, impact, solution

\section{Introduction}

Since December 2019, the world has faced novel coronavirus. As we all know, at present, the problem faced by all countries is how to effectively fight the epidemic and make it disappear completely. Briefly speaking, the novel coronavirus epidemic has become the most terrible problem facing all countries in the world, and it has a major impact on international relations. The novel coronavirus has brought about a complex impact on Sino-US relations declared Liu Jianfei in his paper "impact of the new epidemic on the international pattern" 1 . The epidemic spread very fast, spread rapidly in a very short period of time, spread to all parts of the world. Novel coronavirus cases have been diagnosed in more than 2 million 400 thousand cases in the middle of April 2020, and more than 20 thousand of Africa's cases, Said Dong Xu, in the foundation and challenge of the African COVID-19 prevention and control2. He believed that due to the weak medical system, shortage of living materials, limited government mobilization capacity and unstable political situation in some regions, how to fight the epidemic situation will be a major challenge, and even some African countries will

1 刘建飞新远肺市炎疫情对国际格局的影响 [J].当代世界与社会主义,2020(03):12-19.

2 刘东旭非洲国家新远湖炎狆清斿空的基础与挑战J].中央民族大学学报(哲学社会科学版),2020,47(04):35-41. 
not be able to get out of this difficulty. This paper will study Africa during the epidemic period, and discuss the crisis that Africa may face in the post epidemic era and put forward some countermeasures.

\section{Literature reviews}

Some people say that people in Africa are generally younger, and the number of infected people will not increase rapidly. Judging from the death toll in Africa, this statement is correct, but it is one-sided. If we look at it from other perspectives, we can see that the epidemic has a huge impact on Africa. Research shows that during the epidemic period, African countries have been seriously affected in political, economic, cultural and educational, social life and other aspects. The novel coronavirus has made a significant impact on African countries' economies and foreign trade, and the most direct impact is the reduction of foreign investment, which is not a good thing for African countries3. Novel coronavirus has been reported repeatedly by RFI radio, and many African countries are constantly funding the developed countries. It has a significant impact on every area of life in Africa. Gulam Muhammad and Zhou Yuefeng pointed out that the epidemic may have a significant impact on education in Africa, and put forward relevant action measures4. Novel coronavirus reported nearly 900 thousand of the confirmed cases in the 54 countries and regions in Africa and 190 thousand of deaths were reported in July 30th. According to the proportion of Africa's population, the number is not small. African leaders should unite to face the epidemic, rather than blindly seeking help from developed countries. At present, African countries are facing the impact of the epidemic. In the future, Africa will face more complex and arduous problems, such as debt repayment and social governance5. Therefore, in order to alleviate the problems after the outbreak, African countries should be cautious in lending during the epidemic period; otherwise the loan repayment dilemma will be more serious than the epidemic situation. For poor countries, the epidemic is a disaster.

\section{African epidemic: Causes and consequences}

By the beginning of 2020, the epidemic broke out in an all-round way and rapidly spread to all parts of the world, and each continent continued to become the hardest hit areas of the epidemic. The World Health Organization (WTO) declared the epidemic as a global pandemic6. Studies show that by mid April 2020, there are more than 2.4 million confirmed cases in the world, including more than 20000 confirmed cases in Africa. According to the latest epidemic statistics, the number of confirmed cases in Africa has exceeded 1

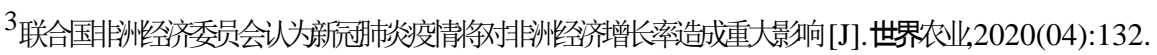

4古拉姆・穆罕默德, 周岳峰.新冠肺炎疫情对非洲高等教育的影响 [J].世界教育信息,2020,33(07):31-32+35.

5 《Quel avenir pour l'economie africaine》, l'institut mines-telecom,aout 2019,page 3

6谭德赛.从12019冠状病毒䖉埥中健康复苏宣言—第七十三届卫生大会 $[$ R].世界卫生组织, 2020.
} 
million. It has not only affected all aspects of the epidemic, such as human and economic, but also the impact on human and social life.

\section{1) Causes of the epidemic in Africa}

The main reasons for the outbreak and rapid spread of the epidemic in Africa are as follows:

African people who have been repatriated from France in the beginning of 2020: France was one of the countries initially affected by the epidemic. Many African researchers and medical staff say the source of the outbreak in Africa is the people repatriated from France in early 2020. The researches show that some of these people are affected by novel coronavirus. Novel coronavirus carriers from European countries have been inaccessible to Africa in the early stages of the epidemic because of inadequate control of imported cases. This has become a major case of early African epidemic and the main source of community communication. In other words, the main reason for the outbreak of African epidemic was those people repatriated by French government, declared Liu Dongxu7 .

People's group in public places: Novel coronavirus is a respiratory infectious disease. Usually, markets, nightclubs, bars, railway stations, bus stations, airports, ports, schools, sports grounds, churches and other public places are densely populated, which are the hardest hit areas for the spread of the virus. The researchers said the novel coronavirus is highly contagious. As long as there is an infected person, it will spread from one to another, leading to a large number of people infected. We know that many parts of Africa are still living in groups. Some African families have more than 40 members, who not only live together, but also eat together. This makes no difference between home and public places. In this case, if a family member is infected, the whole family will be infected certainly. In addition to these two reasons, of course, there are many other reasons, such as the lack of masks and testing equipment in some areas.

\section{2) The impact of the epidemic on the African continent}

The outbreak of the novel coronavirus in 2020 has caused great impact on political, economic and educational fields. The World Health Organization (WHO) put forward in the "Declaration on rehabilitation from the 2019 coronavirus epidemic" that the epidemic is the biggest impact on the world in more than a decade, and the world economy is likely to face the most serious recession since 1930. A novel coronavirus outbreak will cause unemployment and income loss, which will be harmful to livelihoods, health and sustainable development. In this paper, we can see that consequences of the epidemic in Africa fall into two categories: direct and indirect consequences:

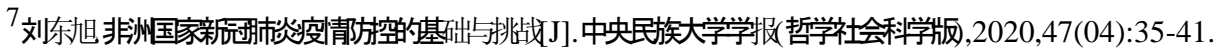




\section{Direct loss of epidemic}

\section{$>$ Political losses caused by the epidemic in Africa}

The study on the epidemic situation in Africa shows that the epidemic has a significant impact on political activities of African countries. Since the outbreak of the epidemic in Africa, African countries have faced many problems in their political activities, which have led to great conflicts between the governments and citizens of some African countries. Guinea, for example, was called off because of an outbreak of epidemic. Guinea's State Press stressed that the sudden change in the date of the election created a huge problem between the government and its citizens. African Union Commission peace and Security Commissioner Charge issued a statement saying that the impact of the epidemic on Africa is likely to be long-term, and will delay the election and political reform of African countries. In addition, the epidemic has also led some African leaders to flee overseas, such as France and Turkey. Since the outbreak began on the African continent, people in many African countries have been complaining about the absence of the head of state. It has been proved that the presidents of some African countries have never appeared at national meetings, and are always represented by secretaries or prime ministers. The epidemic has had a negative impact on the foreign affairs of some African countries, as well as the diplomatic relations between African countries, African region and other countries in the world. After the outbreak of the coronavirus, all the borders were sealed off and there was little diplomatic activity.

\section{Economic and trade losses caused by the epidemic in Africa}

The virus outbreak came at a time of good prospects in many African countries. In 2020, Africa's economy will continue to develop, and the growth rate is expected to rise from $2.9 \%$ in 2019 to $3.2 \%$ in 2020 , and reach $3.5 \%$ in 20218 . Based on the damage the epidemic has caused in Africa, these economic estimates are difficult to achieve. On the African continent, economy and trade are the areas most affected by the epidemic. This is mainly because the export of African products to foreign countries faces the problem of border blockade, which leads to the decline of foreign demand for African goods. Because of the trade deficit, the local currency began to depreciate.

The crisis triggered by the epidemic has had a negative impact on the infrastructure construction of the African continent. It has also caused a lot of losses to small and medium-sized enterprises and emerging enterprises in the continent, and even led to the closure of some enterprises. At the same time, the epidemic has also had a great impact on tourism and aviation in Africa. How important is the aviation industry and tourism for African countries, especially in island areas such as Comoros and Madagascar. Research shows that

\footnotetext{
8 Situation et perspectives de l'économie mondiale en 2020, Département des affaires économiques et sociales de l'ONU, 13 mai 2020.
} 
the losses in this field will directly affect other economic sectors, such as accommodation, catering, handicrafts and so on. Recently, the Economic Commission for Africa released a report on the economic impact of the epidemic on the African continent. The report stressed that the virus has had a significant impact on Africa's economic growth rate, which is likely to drop to $1.8 \%$ from the previously expected $3.2 \%$. At a press conference on the impact of the epidemic on Africa's economy held by the Economic and Trade Commission, Secretary Vera songui stressed that the fuel export income of the African continent is expected to decrease by about US $\$ 101$ billion this year, and the income loss of African oil exporting countries is expected to reach as much as 65 billion US dollars9. Prior to the outbreak, Africa's private sector had difficulty accessing markets due to infrastructure constraints, corruption and high costs of doing business, which hindered the creation of new jobs more widely. Now, the virus has further disrupted the market through measures such as travel bans, social segregation and restrictions on economic activity, resulting in a sharp decline in demand for goods and services, especially in sectors such as hotels, tourism, transportation and manufacturing (such as food and beverages) in the local market. Many of the 24.3 million jobs created by tourism are at risk in the short and medium term.

\section{$>$ Social and educational losses caused by the epidemic in Africa}

Social life and education are the two most affected areas in Africa. The results show that the social and educational consequences of the epidemic in Africa mainly include: population loss, increased unemployment, lower consumption, education suspension, etc. According to the latest report on the epidemic situation in Africa, more than 1.56 million cases have been diagnosed and 37000 deaths have been recorded. Judging from the number of confirmed cases and deaths, the epidemic clearly threatens the lives of Africans. Since the outbreak of the epidemic, many Africans have lost their jobs and the unemployment rate is rising, which has led to the food crisis. Many people have been unemployed and have no money to buy necessities because of unemployment, border blockade and other reasons.

Education and training industry is also one of the industries affected by the epidemic situation. The blockade of primary and secondary schools, universities, vocational and technical training centers and other educational institutions deprived people of the opportunity to receive education. Due to the rapid spread of the epidemic, schools and other training institutions have been closed all over the world. Unfortunately, in most parts of Africa, this is not a very viable option because so far many African countries lack technology and equipment for online teaching. UNESCO points out that the direct and long-term consequences of school closures are bound to exacerbate educational inequality on the continent.

\footnotetext{
${ }^{9}$ Selon la CNUCED, les PEID sont les plus vulnérables à l'effondrement du tourisme car ce secteur représente près de $30 \%$ de leur PIB. Dans le cas des Seychelles, il s'agit de plus de 50 \%. Pour les PEID, une baisse de 25 \% des recettes liées au tourisme entraînera une chute de 7,4 milliards de dollars É.-U. au niveau du PIB, soit 7,3\%.

This publication is licensed under Creative Commons Attribution CC BY.

http://dx.doi.org/10.29322/IJSRP.11.01.2021.p10965

WwW.ijsrp.org
} 


\section{- Long term loss of epidemic}

Judging from the losses caused by the current epidemic on the African continent, African countries will face very serious losses in the fields of politics, economy, society and education after the epidemic. Although the African continent had great problems in all aspects before the outbreak, this paper believes that these problems will be more serious after the epidemic.

\section{Political field}

According to the political system of African countries, Novel coronavirus will be politically unstable, corrupted and related,. In other words, after the outbreak, African politics is likely to fall into chaos.

\section{Economy and trade}

African countries have the most loans in the world. Due to the shortage of funds, countries have to borrow from developed countries and international organizations. Judging from the development situation of African countries, many countries will be unable to repay the loans provided by developed countries and international organizations after the outbreak. The immediate consequence of failing to repay these funds is that countries will offset their loans by exploiting mineral resources. In addition, due to the lack of funds, private or state-owned enterprises will face difficulties or even collapse. The decline in the prices of agricultural products and animal products will undoubtedly lead farmers to give up these basic economic activities. The stagnation of transportation and tourism will further increase the economic burden of African countries.

\section{Social and educational fields}

In terms of society, after the outbreak, countries will have to face the following crises, such as poverty, hunger and social violence. At present, due to the rapid development of the epidemic situation, the number of unemployed people is increasing, and the factors of social instability are also increasing rapidly. What's more, terrorist organizations will come back again. If African leaders fail to take timely and effective measures to solve these problems, African society will fall into a more serious crisis.

In terms of education, after the epidemic, education of various countries will also face great difficulties. For example, many private schools rely mainly on students' tuition fees to maintain their operations. Because of the high tuition fees, parents are unable to work or lose their jobs due to the impact of the epidemic, which makes it impossible to pay for their children's tuition. Therefore, unless the local government provides assistance to these private schools, they are likely to face the risk of bankruptcy. There is a saying in Cameroon Dialect: "schools are not built for the poor people", which means that when you are poor; don't think about going to school. Only the children of the rich can go to school. This is a long time ago, but affected by the epidemic, African education is likely to return to its original state. Poor people can't even eat, let alone pay school fees. In addition, after the end of the epidemic, African women will be deprived of the right to education and will have to marry early. Some parents will even use the bride price of their 
daughters to ensure that their sons can go to school. The closure of schools and educational institutions will have a negative impact on girls' education. They will not only be unable to go to school, but also face problems such as early marriage, early pregnancy and various forms of violent crimes. What's more, the number of African students studying abroad will decrease after the epidemic. This could lead to a shortage of talent on the continent.

\section{Measures to prevent and control epidemic situation in Africa and suggestions for coping with post epidemic crisis}

As everyone knows, the outbreak of novel coronavirus has brought incalculable losses to the countries all over the world, and even led to a serious decline in GDP in some countries. At present, the problem faced by governments all over the world is how to protect the health and safety of citizens and eliminate the epidemic completely. During the outbreak, many governments, like the Chinese government, put national health and safety first. Only when people are healthy can political, economic and educational activities be carried out smoothly. The losses caused by the epidemic to the development of countries around the world may affect the future development of their countries. Therefore, countries affected by the epidemic should consider how to deal with various problems after the outbreak. This section will describe the measures to prevent and control the epidemic in Africa and provide some suggestions for dealing with the crisis after the outbreak in Africa.

\section{A. Prevention and control measures in Africa}

Like other countries, African countries have taken various measures to fight the epidemic during the outbreak. Due to the backward infrastructure and the shortage of public health care in African countries, governments can only take the most basic protective measures, such as stopping work, stopping production, suspending school and closing public places. In addition, African governments have been concerned about the following prevention and control measures: pay attention to hygiene, more ventilation, less party, more exercise, etc. In short, what African governments can do during an epidemic is to protect people's health and safety. It's good for African governments to put life first, especially during pandemics.

\section{B. Africa's response to post epidemic crisis}

African countries are likely to face many problems after the complete end of the epidemic, such as political turmoil, economic crisis, food crisis and so on. If governments do not take active measures to prevent them, these crises may last for five years on the African continent. Therefore, this paper not only puts forward the crisis that Africa may face after the epidemic, but also puts forward some important suggestions to help Africans cope with these crises actively.

\section{Political field}


African countries should consider improving existing systems to provide more job opportunities for young people in a position to do so. The president of Cameroon, Paul Biya, once said that "youth are the leaders of a country", that is to say, the development of a country cannot be separated from the youth. It can be seen that one of the ways for African countries to get out of the crisis after the outbreak is to believe in the ability of young people and involve them in political affairs. Old African politicians are often limited to maintaining national peace and security, while young politicians, in addition to safeguarding national security, will creatively promote the development of other social sectors.

It turns out that some African leaders did not use the funds borrowed from developed countries to help the people affected by the epidemic, let alone to protect the national health and safety. Instead, they use the money as their own property to meet their own consumption. In order to alleviate the debt crisis that African countries may face after the epidemic, it is necessary for African countries to strengthen the construction of clean and honest government, strengthen the public supervision system, and truly achieve "taking from the people, using it for saving people's life".

\section{Economy and trade}

Economy is the main force in the development of a country or region. Problems in the economic field can easily affect the development of other areas of the country. After the epidemic, returning to work and production will be the top priority.

African countries should increase investment in agriculture, fisheries and animal husbandry, and encourage young people in cities to actively participate in agricultural production. The government should also help farmers and provide them with the necessary means of agricultural production. In China for example, "agriculture, rural areas and farmers" have always been the focus of the government. Only when the peasants are rich can the country become rich and powerful. Agriculture can not only reduce the famine that African countries may face after the epidemic, but also promote the rapid development of African economy.

African countries should set up assistance agencies in five African regions (East Africa, West Africa, South Africa, North Africa and Central Africa) to provide economic assistance to the countries most affected by the epidemic. African countries should also set up technical training centers to strengthen the training of young people so that they can master advanced production technology and effectively promote economic development. Qualified African countries should vigorously develop Internet trade and promote trade development and industrial upgrading through online trading platforms. Governments also need to work to restore tourism and aviation to their vitality and solvency, including loan guarantees and temporary tax exemptions.

Moreover, African governments should not ask for foreign aid endlessly. Before applying for assistance, comprehensive consideration should be given to the national conditions. African countries should not accept the free aid from the former colonial countries, because it is likely to have hidden secrets. Research shows that, so far, many African countries still have no right to manage their own natural resources, while the forklift trucks exploited are in the hands of multinational energy companies and the capital behind them. Natural 
resources play an important role in the economic construction of African countries. Therefore, African governments should seek their own legal rights in order to quickly resume economic production after the epidemic. At the same time, governments should strengthen win-win cooperation with Asian countries and achieve win-win cooperation through the political concept of "fairness and mutual trust".

\section{Social and educational fields}

African governments should consider creating more employment opportunities so that young people can support their families and actively participate in nation building. At the same time, each community should establish a professional team to advise unemployed street youth and encourage them to participate more in agricultural production and other legal work. This not only helps to reduce the number of street gangsters, but also makes a great contribution to the local economic construction.

We should strengthen the social protection system, ensure that the elderly, the weak, the vulnerable groups and the people in difficult situations can get help in time, reduce the medical expenses, prohibit early marriage, actively safeguard the rights of African women, and encourage them to receive good school education. This not only helps to reduce the phenomenon of children living on the streets, but also helps to train women to participate effectively in the development of national politics, economy and other fields10.

Some people say that education is the door to a happy world. Parents can sacrifice everything for the education of their children. The state should also sacrifice everything for the education of the people, because education is an important force for national development.11

In addition, governments should set up special funds for studying abroad. Through the establishment of a selection mechanism, students from poor families can be selected and sent to study abroad by government. After they have completed their studies and returned home, they can apply their advanced technology to national construction. This can not only change the fate of poor children, but also improve national productivity, which can be described as killing two birds with one stone.

\section{Conclusion}

Corona virus pandemic is one of the most serious epidemics in human history. It swept the whole world in a short time and caused very serious losses. This paper studied the situation after the outbreak in Africa. The research contents mainly include: firstly, this paper described the losses caused by the epidemic in Africa from the aspects of politics, economy and trade, society and education, and listed the protective measures taken by African countries during the epidemic period; secondly, it mentioned the problems or

${ }^{10}$ COVID-19 and the future of word in africa:How to reduce income loss for formal sector employees,ecLouise Fox and Landry SignéThursday, May 21,2020

${ }^{11}$ UNESCO, Incidences socio-economiques et culturelles de la COVID-19 sur l'Afrique, Reponse de l'UNESCO 
challenges that African countries may face during the epidemic period; finally, this paper discussed the problems that African countries may face after the epidemic and made Some suggestions that have been put forward.

After the outbreak of the epidemic, African countries will not only face political crisis, economic recession, food shortage and other problems, but also face enormous pressure to repay loans. Therefore, the main purpose of this study is to let more African government officials and its foreign friends understand the problems that Africa will face after the outbreak. In order to reduce the negative impact of COVID-19, African governments should always maintain a sense of crisis and take precautions to minimize the impact of the epidemic.

\section{REFERENCES}

[1]＼cjkstart刘建飞新䛃肺市炎疫情对国际格局的影响 [J].当代世界与社会主义,2020(03):12-19.

[2] 刘东旭.非洲国家新冠肺炎疫情防控的基础与挑战 [J].中央民族大学学报 (哲学社会科学版),2020,47(04):35-41.

[3]＼cjkstart联合国非洲经剂委员会认为新完朋炎疫情将对非洲经剂曾长率造成重大影响 [J].世界农业,2020(04):132.

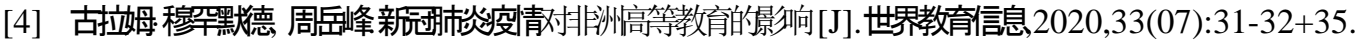

[5] 《Quel avenir pour l'economie africaine》,l'institut mines-telecom,aout 2019,page 3

[6]＼cjkstart谭德赛从从2019冠状病毒没|青中健康复苏宣言一第七十三届卫生大会[R].世界卫生组织, 2020.

[7] Situation et perspectives de l'économie mondiale en 2020, Département des affaires économiques et sociales de l'ONU, 13 mai 2020.

[8] Selon la CNUCED, les PEID sont les plus vulnérables à l'effondrement du tourisme car ce secteur représente près de $30 \%$ de leur PIB. Dans le cas des Seychelles, il s'agit de plus de $50 \%$. Pour les PEID, une baisse de $25 \%$ des recettes liées au tourisme entraînera une chute de 7,4 milliards de dollars É.-U. au niveau du PIB, soit 7,3 \%.

[9] COVID-19 and the future of word in africa:How to reduce income loss for formal sector employees,ecLouise Fox and Landry SignéThursday, May 21, 2020t

[10] UNESCO, Incidences socio-economiques et culturelles de la COVID-19 sur l'Afrique, Reponse de l'UNESCO

AUTHORS

\section{DEGREUME degbar91@qq.com}

